\title{
Strategi Guru dalam membangun komunikasi dengan Orang Tua Siswa di Sekolah
}

\author{
Ike Junita Triwardhani ${ }^{1}$, Wulan Trigartanti ${ }^{2}$, Indri Rachmawati ${ }^{3}$, Raditya Pratama Putra ${ }^{4}$ \\ 1,2,3,4 Universitas Islam Bandung, Bandung, Indonesia
}

\begin{abstract}
ABSTRAK
Membangun kegiatan belajar mengajar yang efektif di sekolah memerlukan peran guru, anak dan juga orang tua. Komunikasi yang efektif dapat menjamin berlangsungnya interaksi antara guru, siswa, dan orang tua secara optimal. Penelitian ini memilih Sekolah Dasar Tunas Unggul sebagai kasus penelitian. Sekolah ini memiliki konsep yang kreatif dan inovatif dengan memandang pentingnya keterlibatan orangtua dalam pendidikan di sekolah, dengan cara yang unik sekolah mengembangkan metode yang diberi nama My Conference dimana dengan metode tersebut keterlibatan orang tua secara aktif dalam pendidikan disekolah dapat terbangun dengan baik. Penelitian ini dilakukan dengan metode studi kasus yang pengamatannya terpusat pada komunikasi yang dilakukan guru untuk membangun keterlibatan orang tua dalam proses pendidikan di sekolah. Merumuskan pola komunikasi yang dilakukan guru dalam membangun keterlibatan orang tua menjadi tujuan dari penelitian ini. Dimulai dengan memetakan bagaimana guru menerjemahkan kurikulum untuk anak, kemudian mengembangkan strategi komunikasi dalam membangun keterlibatan orangtua. Guru menerjemahkan kurikulum dengan berbagai cara yang menarik. Kemampuan memahami materi, berdiskusi, menjawab pertanyaan sampai pada mengelola berbagai kegiatan pembelajaran. Kemampuan menciptakan berbagai program yang mensyaratkan keterlibatan orang tua dalam berbagai kegiatan anak di sekolah menjadi wadah komunikasi yang menarik. Pola komunikasi guru dalam membangun keterlibatan orang tua di sekolah terbentuk karena ketertarikan orang tua terhadap berbagai program belajar dan kehadiran disekolah dengan semangat karena memang menarik, merasa nyaman dan adanya kebutuhan untuk mengikuti dan mendorong program belajar anak.
\end{abstract}

Kata-kata Kunci: Komunikasi; Guru; anak; pendidikan anak; orang tua

\section{Teacher's communication strategies in building Parent engagement at School}

\section{ABSTRACT}

Building effective teaching and learning activities in schools requires the role of teachers, children and parents. Effective communication in school ensures optimal interaction between children, teachers and parents of the students. The research case chosen was Tunas Unggul elementary school in Bandung. In this school parental engagement is very important. this schools have a method called "my conference" whereby teachers can build active parental engagement in children's education at school. With the concept of innovation and creativity, education is developed in a unique way that builds the involvement of parents and teachers and students in learning activities in school. This research used case study method to analyze how is Teacher communication patterns in building parental engagement in children's science education are done through the stages of translating curriculum for children, mapping the way teachers in building communication, developing teacher communication strategies in involving parents in children's educational activities and compiling patterns of teacher's communication in building parental engagement. The teacher translates the curriculum in various interesting ways. The ability to understand the material, discussion, answers the questions and manages various learning activities. The ability to create various programs that require parents' engagement in various children's activities at school becomes an interesting communication method. Teacher's communication patterns in building parental engagement in teaching in school are formed due to parents' interest in various learning programs and attendance at school with enthusiasm because they are interesting, comfortable and there is a need to follow and encourage children's learning programs.

Keywords: Communication; Teacher; child; children's education; parents

Korespondensi: Dr. Ike Junita Triwardhani. M.Si., Universitas Islam Bandung, Jl. Tamanasari No. 1 Bandung.Email: junitatriwardhani@gmail.com 


\section{PENDAHULUAN}

Pendidikan yang dilaksanakan dengan baik akan menghasilkan generasi yang unggul. Sekolah hendaknya dapat mengembangkan program yang kreatif dan inovatif dalam membangun pendidikan untuk menghasilkan generasi unggul tersebut.

Inovasi pembelajaran dapat dilakukan dengan melibatkan berbagai pihak yang berkaitan dengan sekolah. Keterlibatan berbagai pihak dalam proses pendidikan akan menghasilkan keberagaman, kolektivitas, variasi, dan seleksi dalam interaksi antar pelaku yang terlibat dalam proses pendidikan tersebut, yang dapat dipetakan dalam 4 aspek: keterlibatan, kepentingan, penempatan diri, dan pembentukan kepedulian Bersama (Fuglsang, 2008). Pendidikan perlu dibangun sejak dini karena menyangkut hal penting yang dapat menciptakan daya kompetitif dari seseorang, sekelompok orang dan lingkungan masyarakat.

Setiap siswa pada dasarnya memiliki potensi, adalah tugas sekolah untuk mengembangkan setiap potensi tersebut, namun pengembangannya memerlukan strategi yang tepat dari pihak sekolah yang sekaligus melibatkan orang tua untuk terlibat dalam pelaksanaan kegiatan belajar mengajar (Axelsson, Hägglund, \& Sandberg, 2015).

Sekolah perlu menciptakan strategi yang kreatif dan inovatif dalam mengembangkan pendidikan, untuk menciptakan dan meningkatkan kemanfaatan nilai-nilai bagi masyarakat, kreativitas dan inovasi yang ditonjolkan dalam pendidikan di sekolah harus berorientasi pada inovasi sosial sehingga anak memiliki orientasi untuk menghasilkan hal-hal yang bermanfaat bagi masyarakat (Nauta, Jong, \& Cels, 2012). Kreativitas yang digali dari siswa akan menumbuhkan nilai positif dalam pembelajaran, selain siswa menghasilkan hal yang bermanfaat bagi masyarakat, siswa juga dituntut menjadi seorang yang mampu menemukan hal baru dan menciptakan suatu yang bermanfaat bagi pembelajarannya.

Karakter-karakter dasar yang dibangun pada diri anak dapat menumbuhkan nilai positif yang dapat menjadi kekuatan bagi peningkatan daya saing mereka kelak ketika sudah dewasa. Kelak mereka akan memiliki sejumlah pengalaman yang terakumulasi menjadi sekumpulan pengetahuan yang digunakan untuk modal menginterpretasikan, memahami berbagai fenomena yang dihadapi di masa yang akan datang serta menjawab berbagai tantangan yang muncul (Yu, 2009).

Kemampuan anak harus dikembangkan secara menyeluruh melalui pendidikan (Christianti, Cholimah, \& Suprayitno, 2015). Berbagai aspek pada diri anak harus dikembangkan. Guru tidak bisa hanya fokus pada aspek kognisi saja. Membangun karakter anak menjadi faktor penting tercapainya tujuan pendidikan yang sesungguhnya. Karakter dapat dibangun melalui kemampuan anak dalam mengembangkan kreativitas dan kemampuan yang dimiliki.

Membangun karakter pada anak memerlukan upaya yang besar. Berbagai kendala akan muncul dalam pelaksanaan komunikasi dalam sebuah sekolah. Sekolah perlu membangun komunikasi dengan orangtua, karena proses interaksi orang tua dengan anak jauh lebih intens dan terbuka maka melibatkan orang tua dalam pendidikan sekolah untuk membangun karakter anak menjadi pilihan yang baik.

Interaksi yang terjadi antara tiga komponen penting dalam proses pendidikan yaitu guru, orang tua dan anak, menjadi fokus dalam tulisan ini, di mana ketiga komponen tersebut saling berinteraksi dalam proses belajar mengajar sehingga membentuk lingkungan pendidikan yang baik. Tujuan dalam penulisan ini adalah untuk memetakan bagaimana guru melakukan pendekatan melalui komunikasi dalam mengajar, menganalisis bagaimana guru berinteraksi dengan anak-anak di sekolah, dan memetakan bagaimana guru berkomunikasi untuk mendorong keterlibatan orang tua siswa dalam proses belajar di sekolah.

Lingkungan pendidikan yang baik melibatkan berbagai pihak dalam proses belajarnya. Guru, siswa dan orang tua adalah komponen utama yang terlibat dalam proses belajar mengajar, interaksi yang baik antara tiga komponen tersebut dapat mendukung hasil belajar yang optimal.

Guru dan siswa merupakan komponen yang utama dalam proses belajar yang terjadi di berbagai sekolah pada umumnya. Namun seiring dengan makin kompleksnya permasalahan dalam dunia pendidikan, peran orang tua menjadi penting. Melibatkan orang tua siswa dalam proses belajar di sekolah memang 
tidak mudah. Memerlukan pengaturan, motivasi dan porsi serta peran yang tepat sehingga tidak tumpang tindih dengan peran guru serta pihak lain di sekolah. Untuk mendapatkan hasil yang optimal, keterlibatan komponen-komponen utama dalam pendidikan yaitu guru, orang tua dan anak di sekolah harus dikelola dengan baik (Chandran \& Ariffin, 2015).

Guru adalah motor dalam menggerakkan pendidikan di sekolah. Sebagai motor sekaligus komunikator guru berinteraksi dengan berbagai komponen pendidikan, diantaranya anak, orang tua dan guru lain. Guru dan siswa merupakan bagian dari sistem pendidikan yang membutuhkan interaksi yang tinggi. Oleh karena itu, guru dan siswa perlu menjalin komunikasi positif, guru harus memiliki kemampuan berkomunikasi yang efektif dengan siswa dan orang tua (Astiti, Suminar, \& Rahmat, 2018).

Komunikasi yang efektif idealnya dapat mengoptimalkan interaksi antara berbagai komponen pendidikan sehingga tercipta kebersamaan dalam proses belajar mengajar untuk mencapai hasil yang maksimal. Namun dalam kenyataan di lapangan seringkali ditemukan kendala dalam komunikasi. Membuat program yang melibatkan guru, anak dan orang tua memiliki tingkat kerumitan yang tinggi terutama ketika menghadirkan orang tua dalam kegiatan belajar. Karenanya pihak sekolah, terutama guru perlu membangun komunikasi dengan orang tua sehingga orang tua terlibat langsung dalam proses belajar tidak hanya sebagai pengamat saja.

Membangun pola komunikasi yang menyenangkan dan nyaman dapat dilakukan dengan proses komunikasi yang mudah melalui berbagai media komunikasi, tidak hanya melalui proses komunikasi tatap muka, namun melalui media juga menjadi salah satu sarana yang tepat untuk menumbuhkan komunikasi yang efektif.

Menciptakan kenyamanan dalam berkomunikasi memerlukan empati. Kesediaan untuk berada pada posisi orang lain membuat komunikasi menjadi lebih nyaman untuk lawan bicara. Guru harus memiliki informasi, mengerti kondisi orang tua siswa sehingga mampu berempati dan orang tua siswa merasa nyaman dalam berkomunikasi.

Pendidikan di sekolah sangat membutuhkan keterlibatan orang tua untuk mewujudkan proses pendidikan yang lengkap. Tidak terpisah antara program belajar dari sekolah dan pola asuh anak di rumah. Semuanya saling berkaitan dan akan memberikan hasil yang maksimal. Ketika di rumah, anak akan melakukan aktivitas dan berkomunikasi dengan orang tua dimulai dari bermain hingga belajar, namun ketika berada di sekolah, anak akan berinteraksi dengan guru. Oleh karena itu, perlu adanya pengetahuan karakter dari setiap siswa dari adanya kesinambungan dan keselarasan antara kegiatan belajar di lingkungan sekolah dengan pendidikan di rumah. Sebagaimana menurut Wisman (2017) bahwa guru akan sukses dalam melakukan pengajaran terhadap siswanya, dengan adanya pemahaman karakteristik siswanya.

Bagi orang tua siswa membangun keterlibatan di sekolah melalui komunikasi dengan guru sekaligus menyelaraskan pola asuh di rumah dengan apa yang diperoleh anak di sekolah. Segala permasalahan termasuk kendala anak maupun kelebihan anak bisa dikomunikasikan dengan guru. Sehingga membangun tingkat kognisi dan kepribadian anak akan seiring dengan apa yang dilakukan di rumah dan di sekolah. Ide-ide cemerlang orang tua juga akan dapat mendorong programprogram di sekolah. Hal ini yang mendorong selalu terjadi komunikasi antara guru dan orang tua dalam kegiatan belajar anak di sekolah. Melalui komunikasi yang dijalin dengan baik, tentunya akan menumbuhkan rasa kepercayaan yang penuh dari orang tua terhadap pihak sekolah, dan memberikan penilaian positif.

Komunikasi yang dibangun guru dengan orang tua siswa memerlukan berbagai upaya. Komunikasi awalnya akan terjalin dengan kesan yang dibangun oleh kedua belah pihak. Membangun kesan positif sehingga orang tua mempersepsi guru dengan baik. Persepsi adalah aktif dan bukan proses yang pasif, sehingga akan memberikan pengaruh terhadap orang yang diajak berkomunikasi. Pesan yang kita kirim akan sangat bergantung pada bagaimana orang melihat kita apakah akan mengikuti atau tidak dan juga bergantung sedalam apa mampu memahami orang lain (DeVito, 2012). Kesan positif dan menarik akan mendorong seseorang untuk melihat dan berusaha memahami pesan yang disampaikan. Pesan yang disampaikan perlu dengan adanya kejelasan informasi sehingga orang tua mau ikut berpartisipasi dengan adanya kegiatan yang diselenggarakan oleh sekolah. 
Sekolah Tunas Unggul Bandung melibatkan orang tua secara aktif dalam proses belajar mengajar di sekolah. karenanya sekolah ini dipilih sebagai kasus penelitian. Sekolah ini dipilih dengan pertimbangan Kegiatan belajar yang melibatkan orang tua siswa diantaranya adalah melalui program My Conference.

Keterlibatan orang tua dalam kegiatan pembelajaran menjadi hal penting untuk mengembangkan karakter siswa melalui proses komunikasi yang ada. Keterlibatan orang tua tersebut membantu dalam memudahkan proses belajar melalui interaksi komunikasi diantara orang tua dan anak. Hal tersebut sebagaimana menurut Rini (2014) bahwa interaksi yang dibangun antara orang tua dan anak dalam keluarga terjalin melalui interaksi komunikasi yang dilakukan sehari-hari dan setiap aktivitas yang dilakukan antara orang tua dan anak dapat menentukan interaksi komunikasi di antara keduanya.

Mendorong keterlibatan orang tua di sekolah sangat tidak mudah. Hal yang umum terjadi orang tua siswa hanya datang pada saat menerima rapor atau ketika anaknya bermasalah disekolah. Padatnya waktu aktivitas orang tua menjadi sebuah salah satu kendala. Berbeda dengan apa yang terjadi di sekolah dasar Tunas Unggul. Dengan adanya pendekatan khusus yang dilakukan oleh Sekolah Dasar Tunas Unggul, kendala tersebut dapat diminimalisir. Guru juga menerapkan strategi komunikasi agar orang tua terus terlibat dalam proses belajar anak di sekolah. Dengan kreativitas dan inovasi program pembelajaran terus dikembangkan. Berbagai materi pembelajaran dikembangkan bersama antara anak, guru dan orang tua siswa.

Tulisan ini juga bertujuan untuk menganalisis bagaimana guru membangun komunikasi dengan orang tua siswa, membangun komunikasi dengan anak dalam berbagai kegiatan pembelajaran, dan juga strategi komunikasi yang dikembangkan guru dalam melibatkan orang tua siswa pada kegiatan pembelajaran anak di sekolah.

\section{METODE PENELITIAN}

Metode yang digunakan dalam penelitian ini adalah metode kualitatif, dengan pendekatan studi kasus (Yin, 2009) yang memiliki nilai keunikan, yaitu orang tua terlibat dalam proses pembelajaran seperti penyusunan kurikulum, pelaksanaan pembelajaran hingga evaluasi. Yang menjadi sasaran penelitian penulis adalah bagaimana guru di sekolah dasar Tunas Unggul Bandung merancang strategi komunikasi melalui berbagai kegiatan untuk membangun keterlibatan orang tua siswa di sekolah.

Pada metode studi kasus ini data dikumpulkan melalui wawancara terkait dengan proses belajar yang dilakukan di sekolah. Sebagai subjek dan narasumber utama yang diwawancara dalam penelitian ini adalah 5 orang guru SD Tunas Unggul Bandung yang berkomunikasi dengan orang tua dan siswa dalam proses belajar mengajar di sekolah. Keabsahan data dilakukan dengan triangulasi data di mana hasil wawancara pada narasumber utama, yaitu guru dan dilakukan pengecekan dari hasil wawancara tersebut untuk keabsahan data melalui orang tua sebagai informan pendukung.

Sedangkan data observasi diperoleh dari pengamatan terhadap kegiatan pembelajaran mulai dari tahap persiapan, pelaksanaan, hingga evaluasi dilakukan selama tiga bulan yaitu dimulai dari bulan Maret hingga Juni 2019.

Pendidikan diharapkan dapat memberikan hasil yang optimal apabila guru, siswa dan orang tua ikut membangun lingkungan pendidikan yang kreatif dan inovatif melalui interaksi yang baik diantara ketiganya. Dengan usaha yang optimal, sekolah dapat memberikan porsi yang seimbang yang mencakup aspek budaya, penguasaan pengetahuan dan keterampilan terhadap peserta didik .

kegiatan pembelajaran di sekolah cenderung menonjolkan kreativitas dan inovasi. Inovasi yang dibangun termasuk inovasi sosial yang ditujukan untuk meningkatkan kemanfaatan dan menciptakan nilai-nilai bagi masyarakat (Nauta et al., 2012). Pendidikan untuk anak harus mengembangkan kemampuan secara menyeluruh (Christianti et al., 2015). Beberapa penelitian tentang komunikasi dalam kegiatan belajar di sekolah sudah dilakukan. Diantaranya penelitian tentang Metode Komunikasi persuasif Guru dalam mengembangkan kreativitas Anak. Hal yang menarik yang dikaji dalam penelitian ini adalah bagaimana guru mengembangkan komunikasi persuasifnya dengan pesan yang mengena pada persepsi anak (Triwardhani, 2011).

Hasil penelitian menunjukkan kedekatan yang dijalin guru dengan anak dapat mengurangi 


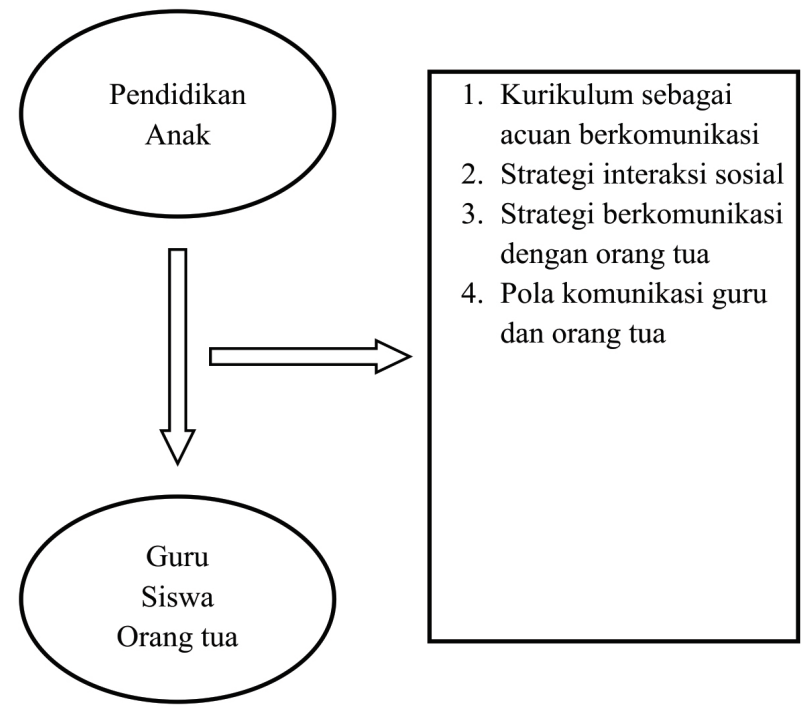

Sumber: Hasil Penelitian, 2019

\section{Gambar 1 Bagan Penelitian}

hambatan anak untuk berekspresi, selanjutnya anak akan terdorong dan terlatih untuk berpikir variatif, inilah yang mendorong berkembangnya kreativitas.

Komunikasi sangat tergantung bagaimana stimulus yang disampaikan dan cara penyampaiannya.

Komunikasi menekankan pentingnya mengelola pesan dengan baik. Dalam mengelola pesan penting untuk mengenal individu yang terlibat dalam komunikasi. Kesesuaian bahasa yang digunakan, pengetahuan dan wawasan yang dimiliki, bahkan kesesuaian konteks terhadap pesan akan memberi pengaruh pada umpan balik yang diharapkan. Pesan yang dikirim atau yang didengarkan sangat tergantung pada bagaimana masing-masing individu mengolah pesan tersebut. Bagaimana memahami dan membangun konteks, dengan siapa kita berinteraksi, perlu diperhatikan (DeVito, 2012). Guru berusaha membangun konteks komunikasi dengan orang tua dan memahami keinginan dan kepentingan orang tua dalam berkomunikasi.

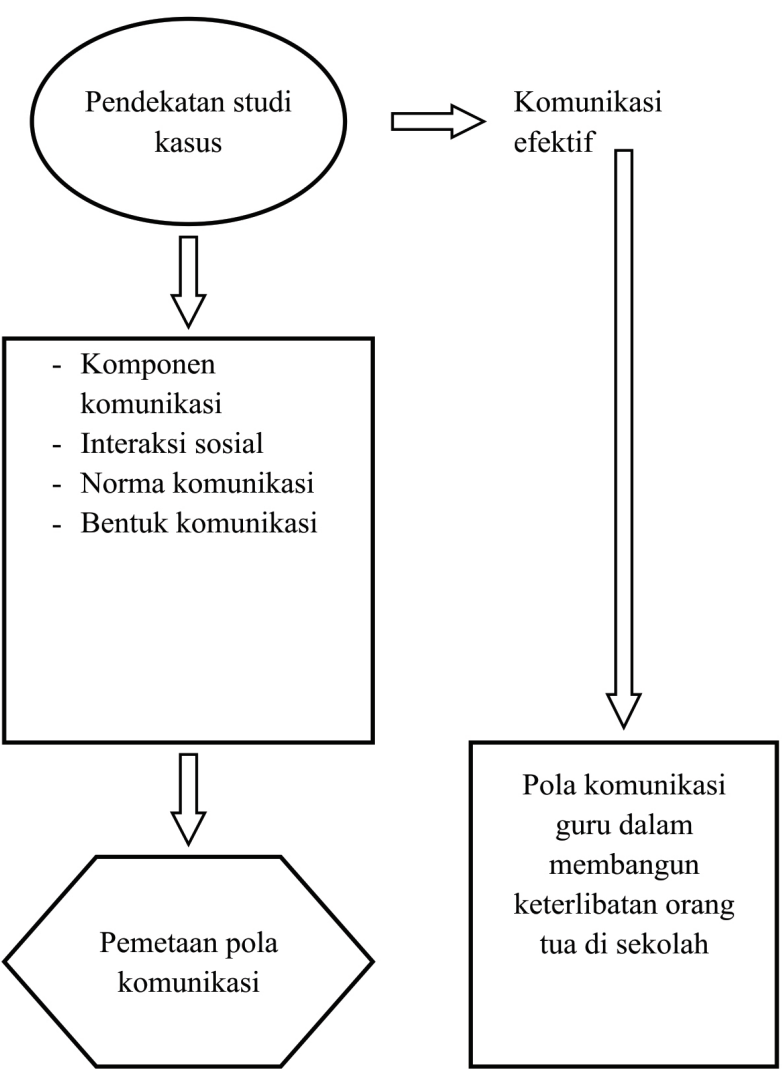

Diantaranya adalah membangun sense dalam berkomunikasi, mengelola pesan dengan baik, menginterpretasi dan mengevaluasi apa yang disampaikan, memperbanyak pengalaman.

Namun tidak semua hubungan terbangun dengan baik. Permasalahan yang muncul dari individu yang terlibat dalam komunikasi mungkin saja muncul karena proses komunikasi begitu dinamis, kondisi bisa berubah sehingga hambatan akan muncul. Perlu upaya untuk mengatasinya sehingga komunikasi akan berjalan secara efektif (Triwardhani \& Chaerowati, 2019).

Kerangka pikir yang menjadi acuan dalam penelitian dapat dilihat pada gambar 1. Gambar ini sekaligus memandu proses monitoring terhadap proses dan hasil penelitian.

\section{HASIL DAN PEMBAHASAN}

Sekolah Tunas Unggul terus berupaya mendidik anak-anak secara optimal melalui pembelajaran yang proporsional, baik 


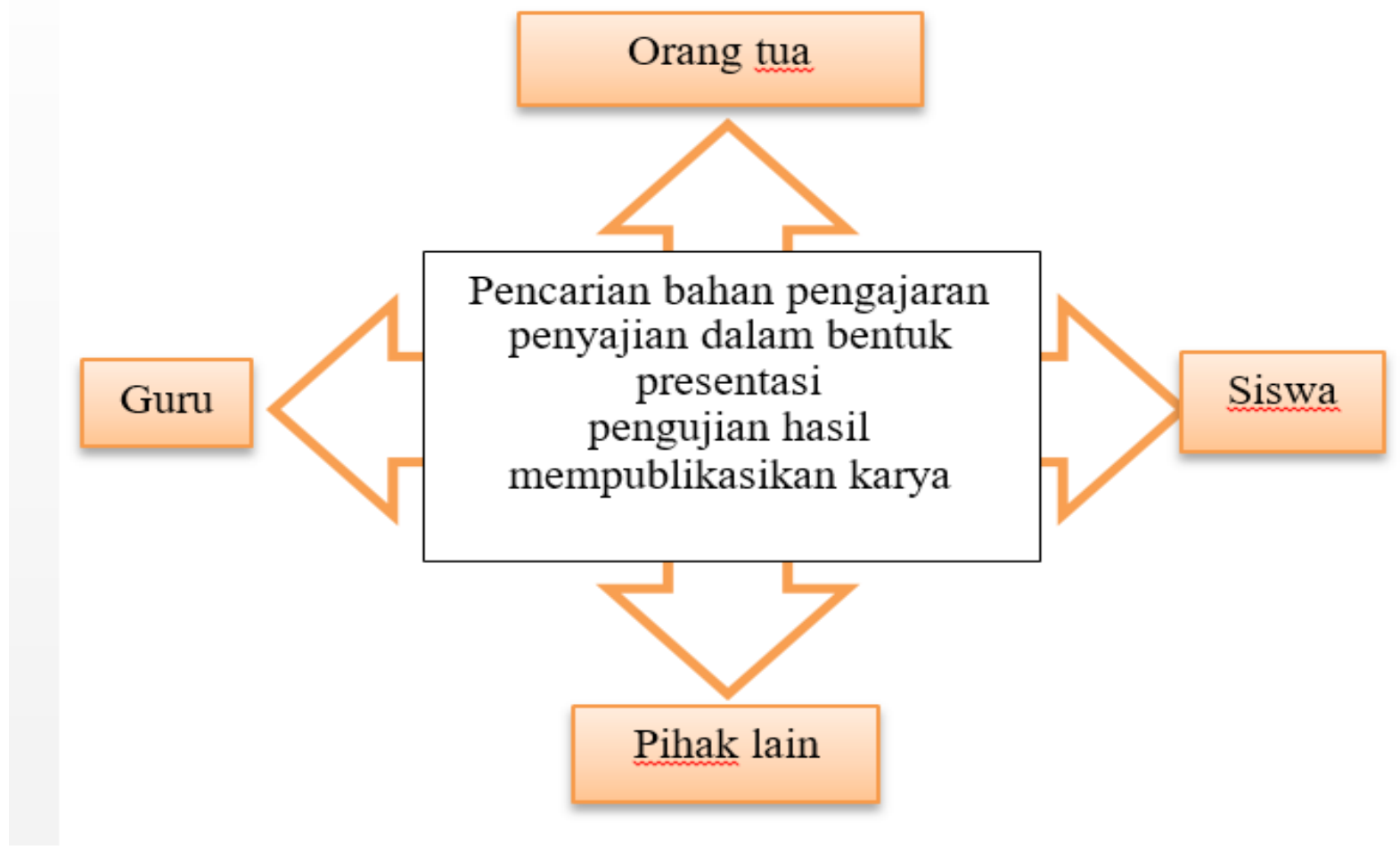

Sumber: Hasil Penelitian, 2019

Gambar 2 Pola Komunikasi Guru dan Anak dalam Pengajaran

kecerdasan intelegensi, emosional, maupun spiritual. Aspek pengembangan diri anak-anak pun diimplementasikan melalui kegiatan yang bervariasi untuk menguatkan Soft Skill dan Hard Skill mereka. Proses pembelajaran di Sekolah Dasar Tunas Unggul terlihat sangat dinamis. Proses belajar mengajar di sekolah tidak hanya melibatkan guru dan siswa secara aktif. Kalau di sebagian besar sekolah dasar sering menemui kehadiran orang tua pada kegiatan pengambilan raport atau kegiatan awal semester, namun pada Sekola Dasar Tunas Unggul keterlibatan orang tua dilakukan pada sepanjang proses belajar mengajar berlangsung.

Ketika awal memasukkan anaknya di SD Tunas Unggul sudah ada pembicaraan dan kesepakatan terlebih dahulu bahwa partisipasi orang tua akan cukup besar selama proses belajar mengajar. Pihak sekolah, guru beserta orang tua siswa bersama-sama dalam penyusunan kurikulum, memantau proses hasil belajar siswa di sekolah, menghadiri kegiatan presentasi, melakukan pengujian, pemberian nilai dan bahkan ikut mengelola kegiatan seperti penerbitan buku hasil tulisan siswa. Berbagai rangkaian kegiatan yang melibatkan orang tua ini sudah berlangsung sekitar lima tahun di sekolah dasar Tunas Unggul Bandung.

Cara guru dalam membangun komunikasi dengan anak pada kegiatan pembelajaran dapat dilakukan melalui proses komunikasi interpersonal. Cara ini dianggap lebih tepat dan efektif karena masing-masing anak memiliki keunikan. Kekhasan ini yang membuat komunikasi kepada anak tidak dilakukan secara umum. Komunikasi interpersonal yang dilakukan oleh guru kepada murid disekolah adalah bentuk komunikasi verbal dan komunikasi nonverbal dalam proses mengajar untuk meningkatkan pengetahuan anak didik tersebut (Pontoh, 2019). Guru sangat memperhatikan kondisi anak ketika di kelas dan memperlakukan anak sesuai dengan kondisi masing-masing.

Kurikulum yang dibangun di Sekolah Dasar Tunas Unggul Bandung melibatkan orang tua, guru dan pihak sekolah. Keaktifan berbagai pihak sangat diperlukan. Sejak awal semester penyusunan materi pelajaran melibatkan pihak orang tua selain siswa dan guru. Guru membangun suasana belajar sehingga siswa mempunyai peran sangat besar dalam proses 
belajar mengajar. Dari mulai mencari berbagai bahan belajar, mendesain cara menyampaikan pada teman-teman, orang tua dan guru, membuat alat peraga sampai dengan membuat kegiatan pembelajaran yang disesuaikan dengan tema pembelajaran saat itu.

Terdapat strategi komunikasi yang dilakukan oleh guru dalam melibatkan orang tua pada kegiatan belajar, seperti halnya yang dilakukan oleh Sekolah Dasar Tunas Unggul yang memiliki berbagai program kreatif dan menarik berkaitan dengan kegiatan belajar dan mengajar anak. Sejak awal penyusunan kurikulum, penerapan dalam kegiatan belajar aktor yang terlibat tidak hanya guru dan anak, tetapi juga orang tua siswa. Guru dalam hal ini terlebih dahulu menafsirkan kurikulum dan menerjemahkannya dengan komunikasi yang dapat dipahami oleh anak. Guru melibatkan orang tua dalam proses pembelajaran untuk anak dimana guru membangun komunikasi dengan orang tua.

Strategi keterlibatan orang tua sudah dirancang sejak awal yaitu melalui berbagai program belajar yang diterjemahkan dari kurikulum dan disesuaikan dengan tema yang sedang berjalan. Berbagai kegiatan belajar mengajar dibangun sekolah melalui guru di mana memungkinkan keterlibatan orang tua siswa sehingga akan meningkat komunikasi dengan guru karena persiapan dan pelaksanaan berbagai kegiatan tersebut.

Kegiatan yang dirancang cukup beragam. Waktu pelaksanaan yang terjadwal dengan baik mulai dari awal tahun pelajaran sampai akhir pelajaran memungkinkan keterlibatan orang tua di sekolah terjadi selama kurun waktu satu tahun pelajaran.

Untuk pelaksanaan rencana agar maksimal, guru perlu membangun kedekatan dengan orang tua. Guru berusaha mendapatkan persepsi yang baik dari orang tua. Dalam membangun persepsi kepada orang tua guru melakukan berbagai upaya. Persepsi akan mempengaruhi pesan apa yang akan kita serap atau stimulus apa yang akan kita tangkap (DeVito, 2012). Perhatian khusus dalam bentuk jalinan komunikasi yang cukup dekat, memberi informasi secara konsisten tentang berbagai kegiatan di sekolah, memberi feed back atau merespons pesan yang dikirim oleh orang tua menjadi bagian dari upaya guru dalam membangun persepsi positif orang tua siswa.
Pentingnya membangun kreativitas menjadi pertimbangan. Kreativitas guru dalam membangun persepsi juga sangat diperlukan. Peristiwa apa saja yang menjadi daya tarik bagi orang tua digarap dengan baik dan melibatkan orang tua siswa mulai dari proses perencanaan, pelaksanaan bahkan pada tahap evaluasi. Daya Tarik ini biasanya ketika orang tua melihat anaknya tampil. Kebanggaan pada anak yang mendorong keterlibatan orang tua pada kegiatan tersebut. Kreativitas dan pemahaman terhadap kondisi orang tua menjadi modal bagi guru membuat penekanan-penekanan agar orang tua tertarik.

Hal menarik untuk mendapat persepsi yang positif adalah menyesuaikan dengan kepentingan lawan bicara, kesesuaian waktu, bahasa yang digunakan, menyesuaikan dengan cara pandang lawan bicara dan menyusun kalimat terlebih dahulu terutama bila berkaitan dengan hal yang penting dan menyangkut banyak orang. Melakukan konfirmasi terlebih dahulu tentang latar belakang masing-masing terutama tingkat pendidikannya akan membuat pesan yang disampaikan lebih efektif.

Kondisi masing-masing komunikan berbeda. Berkomunikasi dengan masing-masing orang tua siswa akan berbeda satu dengan lainnya. Masing-masing memiliki kondisi berbeda. Dengan mengenal kondisi orang tua begitu juga dengan anaknya maka guru akan mudah dalam membangun komunikasi karena akan tercipta kedekatan melalui inti pembicaraan yang khas dengan tema masingmasing orang tua siswa berikut anaknya.

Salah satu hambatan yang sering ditemui dalam komunikasi antara orang tua dan guru adalah masalah waktu. Ketidaksesuaian waktu yang dimiliki karena aktivitas masingmasing pihak yang padat membuat guru harus menyesuaikan waktu menyampaikan pesan agar dapat diterima dengan baik oleh orang tua. Kesalahan waktu dalam pengiriman pesan akan mempengaruhi respons yang diberikan dan sulit memperoleh persepsi yang positif.

Tingkat pendidikan yang dimiliki juga akan mempengaruhi seseorang dalam berkomunikasi. Rata-rata orang tua siswa di SD Tunas Unggul berpendidikan tinggi dan berwawasan luas. Bahasa yang digunakan oleh guru untuk berkomunikasi dengan orang tua siswa juga harus disesuaikan. Bahkan sekolah melatih guru cara-cara berkomunikasi guru secara 
khusus dalam menghadapi orang tua siswa. Pesan yang disampaikan sedapat mungkin tidak bersifat instruksional. Pesan juga tidak hanya sekedar memberikan informasi. Komunikasi dua arah diberlakukan, bahkan informasi yang disampaikan adalah hasil diskusi dengan orang tua siswa. Kedua belah pihak antara guru dan orang tua memiliki peran yang seimbang dalam berkomunikasi.

Memelihara relasi antara orang tua dengan guru sangat tidak mudah. Komunikasi yang berkelanjutan selalu dijaga, respons dari orang tua siswa selalu ditanggapi, ide-ide yang disampaikan diakomodir dengan baik. Berbagai keluhan orang tua yang hanya disampaikan oleh pihak-pihak tertentu saja tetap direspons.

Sekolah juga memiliki program coffee morning khusus untuk mengatasi berbagai permasalahan yang dirasakan orang tua siswa. Dilakukan dialog antara orang tua siswa dengan pihak sekolah melalui guru. Apabila ingin berkomunikasi secara personal, guru juga memberi kesediaan untuk berkomunikasi dengan orang tua siswa secara khusus.

Komunikasi yang dibangun guru juga mengutamakan kenyamanan. Daya tarik, kesediaan dalam berkomunikasi diantaranya adalah dengan menciptakan suasana yang nyaman. Dan penting juga membangun komunikasi yang membuat orang tua siswa merasa senang dan nyaman.

Menciptakan kenyamanan dalam berkomunikasi memerlukan empati. Kesediaan untuk berada pada posisi orang lain membuat komunikasi menjadi lebih nyaman untuk lawan bicara. Guru harus memiliki informasi, mengerti kondisi orang tua siswa sehingga mampu berempati sehingga orang tua siswa merasa nyaman dalam berkomunikasi. Sebagai bentuk empati, guru berkompromi dengan waktu yang dimiliki orang tua. Penjadwalan ulang menjadi solusi keterbatasan waktu orang tua karena pekerjaan di kantor. Guru bersedia berkompromi apabila orang tua menginginkan penjadwalan ulang.

Upaya membangun kenyamanan lainnya diantaranya dengan merahasiakan apa yang disampaikan orang tua sebagai bentuk penghormatan terhadap privasi orang tua maupun siswa. Orang tua akan merasa nyaman berdiskusi atau berbicara apa pun tanpa takut diketahui orang tua lain maupun siswa lain apabila ini berkaitan dengan anak mereka.
Guru juga berhati-hati dalam membicarakan kondisi akademik anak pada orang tua. Semangat dan kebanggaan orang tua pada anak menjadi modal keterlibatan orang tua di sekolah. Hal ini yang terus dibangun guru. Kemajuan anak sekecil apa pun akan terus diinformasikan kepada orang tua.

Guru berusaha membangun pesan yang efektif dengan menekankan tujuan pada keterlibatan orang tua. Pesan yang diinformasikan dikelola dengan baik. Dalam hal ini orang tua tidak hanya sebagai konsumen saja tapi juga menjadi pihak yang terlibat aktif dalam pendidikan di sekolah. Komunikasi yang berlangsung secara efektif di mana salah satu tolok ukurnya adalah orang tua tertarik dengan apa yang disampaikan oleh guru menjadi awal target. Ketertarikan ini akan berlanjut dengan kesediaan orang tua dan bahkan sampai pada kebutuhan orang tua untuk berkomunikasi intensif dengan guru. Bukan sekedar informasi tentang keharusan orang tua menghadiri kegiatan sekolah. Ide-ide gagasan kegiatan sering juga muncul dari orang tua.

Sebagai tindak lanjut dari jalinan komunikasi, muncullah program Guest Teacher di mana orang tua menjadi guru tamu di sekolah. Program ini sebagai wujud terjalinnya komunikasi antara guru, siswa dan orang tua siswa karena melalui program ini orang tua akan mengetahui dan terlibat langsung pada proses pembelajaran.

Ketika berkomunikasi dengan orang tua, guru menggunakan situasi informal agar lebih dapat membangun kedekatan. Komunikasi guru dengan orang tua siswa juga dilakukan di luar jam sekolah baik melalui jalur pribadi maupun melalui grup-grup di media sosial yang sengaja dibuat untuk berkomunikasi dengan orang tua siswa. Untuk membahas masalah yang berkaitan dengan masing-masing siswa biasanya digunakan jalur pribadi, namun tetap disampaikan dalam suasana yang informal.

Dalam berkomunikasi yang harus dihindari adalah menggunakan stereotype, menyinggung masalah yang ada pada keluarga masingmasing. Menggunakan cara pandang sendiri yang sering tidak layak untuk disampaikan karena akan menyinggung lawan bicara. Mengedepankan sikap positif sangat penting dalam berkomunikasi. Walaupun sudah mengenal orang tua dalam waktu yang cukup lama mengingat sekolah dasar ditempuh dalam 
kurun waktu enam tahun, namun tetap melihat orang tua dalam pandangan yang objektif dan mengedepankan cara pandang yang positif. Walaupun banyak masalah yang dialami ketika berkomunikasi dengan orang tua, namun dalam komunikasi berikutnya tidak boleh menggunakan stereotype atau prasangka buruk. Justru dikedepankan melihat hal-hal positif yang dimiliki mengingat kondisi dan suasana komunikasi juga berubah dengan waktu lalu. Sikap positif merupakan hal penting untuk interaksi yang efektif sehingga tercipta iklim komunikasi yang menyenangkan yang dapat mendukung efektivitas komunikasi antara guru dengan orang tua siswa. Sikap positif dalam berkomunikasi akan dapat menggerakkan orang yang berinteraksi dengan kita secara positif juga. Sikap positif akan membuat orang merasa nyaman dalam berkomunikasi dan bahkan menikmati komunikasi yang terjadi.

Untuk berkomunikasi pada orang tua siswa tidak merendahkan tingkat pendidikan atau ekonominya atau membincangkan permasalahan keluarga yang sebenarnya tidak ingin diketahui oleh orang lain. Kemampuan dalam menjaga kerahasiaan akan membuat relasi bertahan lama. Orang tua akan percaya pada guru sehingga komunikasi akan berjalan lebih efektif karena kedua belah pihak dapat membangun kepercayaan.

Guru juga perlu mengenalkan dirinya dengan baik. Kredibilitas sebagai komunikator harus dibangun oleh guru. Kredibilitas yang baik akan membangun kepercayaan, ketertarikan lawan bicara kita. Orang tua siswa walaupun tidak setiap hari berada di sekolah menerima berbagai informasi tentang guru baik dari anaknya menjadi siswa disekolah maupun menangkap kesan dengan berkomunikasi secara langsung. Kredibilitas bisa dibangun dari tingkat pendidikan guru, keahliannya dalam mengajar, wawasan yang dimiliki atau bagaimana kemampuannya ketika mengajar di kelas. Latar belakang tersebut akan diakumulasikan dengan cara guru berkomunikasi dengan orang tua siswa. Kemampuan mendengarkan, memberikan solusi dan ketelatenannya menghadapi keluh kesah orang tua. Semua itu ter akumulasikan dalam kredibilitas guru yang akan berpengaruh pada komunikasi yang berlangsung.

Aspek kedekatan atau proximity akan berpengaruh pada membangun komunikasi yang efektif. Aspek kedekatan termasuk pada bahasan dalam komunikasi. Komunikasi guru dan orang tua siswa diantaranya membahas tentang prestasi maupun permasalahan tentang anak, maka akan terbangun kedekatan terhadap bahasan saat itu yaitu dengan anak yang sedang diperbincangkan bersama orang tua. Hal ini akan membangun kredibilitas guru serta daya tarik orang tua siswa. Kondisi ini juga mempermudah dalam membangun kepercayaan. Ketika berkomunikasi dengan masing-masing orang tua, guru biasanya fokus dan mengerahkan memorinya yang berkaitan dengan anak yang sedang dibahas bersama orang tua. Bahkan guru menggunakan data-data tentang anak yang diperoleh dari keseharian di sekolah atau bisa juga data pendukung dari psikolog di sekolah.

Program atau kegiatan membangun keterlibatan orang tua siswa di sekolah, seperti halnya media portofolio yang digagas sekolah menjadi media untuk mengkomunikasikan kegiatan yang dilakukan oleh anak selama satu semester pembelajaran. Melalui media portofolio, pencapaian kemampuan maupun hambatan anak dalam belajar akan terlihat dengan jelas. Berbagai karya dan kegiatan anak didokumentasikan melalui portofolio masingmasing. Portofolio tersusun sangat rapi sesuai dengan kegiatan yang dirancang oleh sekolah dan diikuti anak.

Pada sesi membedah portofolio antara anak bersama orang tua terjadi diskusi yang menarik antar keduanya. Orang tua memberi pujian sehingga anak merasa bangga. Adakalanya orang tua mempertanyakan kegiatan yang tidak diikuti anak. Namun ada juga sesi menarik ketika sampai pada dokumen kegiatan anak. Orang tua siswa yang memang belum memahami materi meminta anak menjelaskan tentang siklus air. Anak dengan bangga menjelaskan pelajaran sains pada orang tua.

Guru berkomunikasi dengan orang tua melalui mata pelajaran yang didesain menarik dan hasilnya dituangkan dalam portofolio anak. Hal ini mendorong orang tua mendapat kesempatan yang bagus untuk berkomunikasi dengan anak mengenai pembelajaran di sekolah. Media yang digunakan adalah portofolio. Saat membahas portofolio ini, sangat penting peranan orang tua dalam membuat anaknya termotivasi atau, menjadi pasif. Moment orang tua anak dan anak ini menjadi penting agar mengetahui hambatan, atau dorongan anak 
selama proses belajar. Pada pelaksanaannya ada anak yang pasif, yang begitu saja menyerahkan portofolionya pada orang tuanya, dan sang ibu hanya membuka-buka setiap halaman tanpa respons. Namun ada pula orang tua yang bertanya pada sang anak, meski sang anak menjawab sekedarnya dengan gaya manja. Juga tampak ada anak, yang mendapat elusan, pelukan, bahkan senda gurau saat membahas portofolio.

Guru menjadi pendamping dalam kegiatan. Menurut guru pendamping, momen ini penting, melatih anak untuk menceritakan apa yang mereka dapatkan dikelas pada orang tuanya. Saat membahas portofolio ini, sangat penting peranan orang tua dalam membuat anaknya termotivasi atau, menjadi pasif. Moment orang tua anak dan anak ini menjadi penting agar orang tahu mengetahui hambatan, atau dorongan anak selama proses belajar.

Guru terus memberikan peluang-peluang agar orang tua dan anak aktif dalam relasi tersebut. Kesulitan awal yang dialami oleh orang tua dalam menjalin relasi dengan anak di kelas dijembatani oleh guru. Tiba-tiba terjadi hambatan karena anak tidak mampu menjelaskan dan orang tua kehilangan kontrol, maka di sinilah peran guru membantu anak dan memberi pemahaman pada orang tua.

Program menarik lain yang dirancang sekolah dalam pembelajaran adalah $M y$ Conference. Kegiatan ini sekarang menjadi kekhasan dan keunggulan sekolah. $M y$ Conference adalah kegiatan yang dirancang oleh sekolah setiap satu semester sekali. Pada kegiatan ini siswa akan mempresentasikan hasil kegiatannya selama satu semester dengan tematema pelajaran yang sudah ditentukan oleh pihak sekolah. Pada kegiatan ini anak menunjukkan keberanian dan kemampuannya di depan guru, orang tua siswa sendiri maupun temannya.

My conference menjadi acara yang ditunggu-tunggu oleh anak, orang tua siswa dan guru. Bagi guru, my conference seperti puncak atau hasil dari rintisan komunikasi dengan orang tua yang sudah dibangun sejak awal semester. Bagi anak My Conference menjadi ajang untuk menunjukkan keberhasilan dan kehebatan mereka selama belajar di sekolah di depan orang tua masing-masing. Sedangkan untuk orang tua siswa, my conference menjadi kegiatan yang ditunggu untuk melihat perkembangan anak selama di sekolah. Kegiatan my conference juga menjadi ajang komunikasi orang tua dengan guru sekaligus dengan anak dalam waktu yang bersamaan.

Kehadiran orang tua pada kegiatan $M y$ Conference sangat ditunggu-tunggu baik oleh orang tua maupun anak. Kegiatan ini memang sangat menarik. Kemampuan anak menyelenggarakan event sampai mengisi acaranya dengan kemampuan ilmiah mereka sangat luar biasa. Hal ini juga berkat dukungan guru sebagai fasilitator yang hebat. Selain daya tarik kegiatan, yang menjadi magnet bagi kedatangan orang tua di sekolah adalah mereka semua menjadi bagian dari kegiatan ini sejak awal sampai pada acara puncaknya orang tua juga sebagai penilai untuk karya anak. Dalam kesempatan ini orang tua juga diperbolehkan untuk menguji anak.

Sebelum memulai presentasi, orang tua berdiskusi tentang portofolio yang berisi tentang hasil belajar yang diraih sang anak selama tiga bulan. Kemudian dilanjutkan dengan mempresentasikan tugasnya sesuai dengan tema pembelajaran diantaranya adalah menjelaskan siklus munculnya suatu fenomena alam, seperti musim hujan, musim panas, musim gugur, dan musim dingin.

Dari tema yang ada tersebut, berdasarkan tema yang dipilih, siswa akan membuat rancangan kegiatan yang menarik sesuai dengan kreativitas dan pengetahuan yang mereka miliki, kemudian rancangan tersebut yang menjadi bahan presentasi mereka pada My Conference. Dengan membangun nilai kreativitas pada anak tentunya akan menumbuhkan rasa senang pada benak anak ketika mengerjakan tugas tersebut. Dengan adanya perasaan senang ketika mengerjakan suatu proyek sekolah, hasil yang diperoleh akan maksimal. Hal ini sebagaimana menurut (Sucia, 2016) bahwa ketika melakukan kegiatan belajar mengajar dikelas, perlu diciptakannya suasana yang membuat siswa merasa senang, agar siswa merasa nyaman dan semangat dalam mengikuti proses belajar mengajar.

Selain pada program My Conference, sekolah juga memiliki program Guest Teacher sebagai bentuk cara pembelajaran yang kreatif dan menyenangkan, karena pada program ini, orang tua yang bersedia akan menjadi guru di kelas. Materi yang disampaikan berkaitan dengan profesi masing-masing. Tujuan dari program ini adalah membangun keterlibatan 


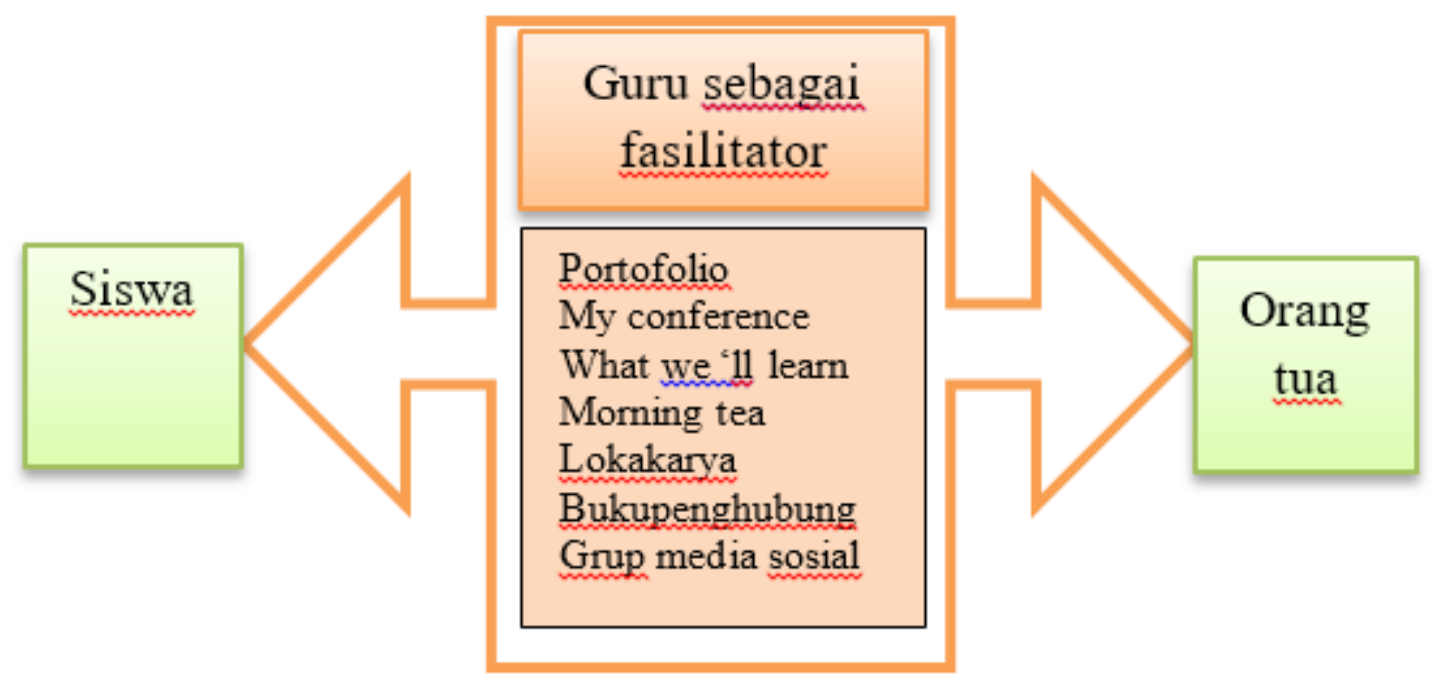

Sumber: Hasil Penelitian, 2019

Gambar 3 Program kegiatan pembelajaran di Sekolah

orang tua pada proses pembelajaran di sekolah serta mengenalkan anak tentang berbagai profesi sehingga anak-anak kelak dapat mulai memilih profesi apa yang akan ditekuni dikemudian hari. Orang tua yang berprofesi sebagai dokter akan mengajarkan tema-tema yang berkaitan tentang kesehatan di kelas. Yang berprofesi sebagai arsitek akan mengajarkan cara membuat sketsa atau pengetahuan tentang bangunan yang baik, ada juga yang mengenalkan tentang dunia farmasi, penerbangan karena profesi orang tua disekolah ini cukup beragam. Untuk merespons kondisi yang secara spontan terjadi, misalnya munculnya masalah atau beredarnya issue atau justru muncul tantangan baru ada program Morning Tea yang diadakan sesuai dengan kebutuhan. Program ini biasanya hadir di semester ke dua, karena sudah banyak proses belajar yang dijalani dan banyak masalah yang ditemukan. Pertemuan ini sifatnya informal, jadi guru dengan orang tua berbincang-bincang santai, kadang masing-masing membawa konsumsi dan dimakan bersama-sama untuk menjalin keakraban. Program Morning Tea mengumpulkan banyak masukan sebagai bahan untuk evaluasi. Komunikasi dibangun dengan memahami apa yang sudah dilakukan oleh sekolah dan apa yang diharapkan oleh orang tua.

Guru perlu terus membangun komunikasi dengan orang tua siswa. Pintu komunikasi harus dibuka sehingga orang tua siswa merasa nyaman. Ruang komunikasi selalu dibuka oleh pihak sekolah seluas-luasnya. Pada satu titik, guru dipertemukan dengan orang tua untuk membahas berbagai hal termasuk masukanmasukan dan kebutuhan setiap kelas atau levelnya, dapat dilihat pada gambar 3 .

Komunikasi Guru dengan orang tua terlihat pada keterlibatan orang tua di berbagai kegiatan anak di sekolah. Orang tua melihat sendiri perkembangan anak. Kegiatan My Conference ini diharapkan ada komunikasi antara orang tua dengan anak. Sekolah melalui guru ingin membuatkan sebuah program di mana anak dan orang tua bisa bertemu yang tidak hanya mengikuti presentasi hasil belajar anak, orang tua juga dapat mengenali potensi anak melalui portofolio anak, sehingga tahu apa saja yang sudah dipelajari anak kurang lebih satu tema dalam satu semester pembelajaran.

Orang tua melihat langsung, merasakan langsung dan bertanya ada hal apa yang ingin kita ditumbuhkan pada diri anak-anak, karena sekolah memiliki student profile, attitude yang menjadi platform sekolah yang akan terus dikembangkan. Keterampilan berkomunikasi, keterampilan kolaborasi, aspek pengembangan lain akan terus dikembangkan oleh sekolah. Orang tua siswa akan melihat, menanggapi, dan juga memberikan input melalui assessment reward kepada anak-anak. Orang tua siswa akan 


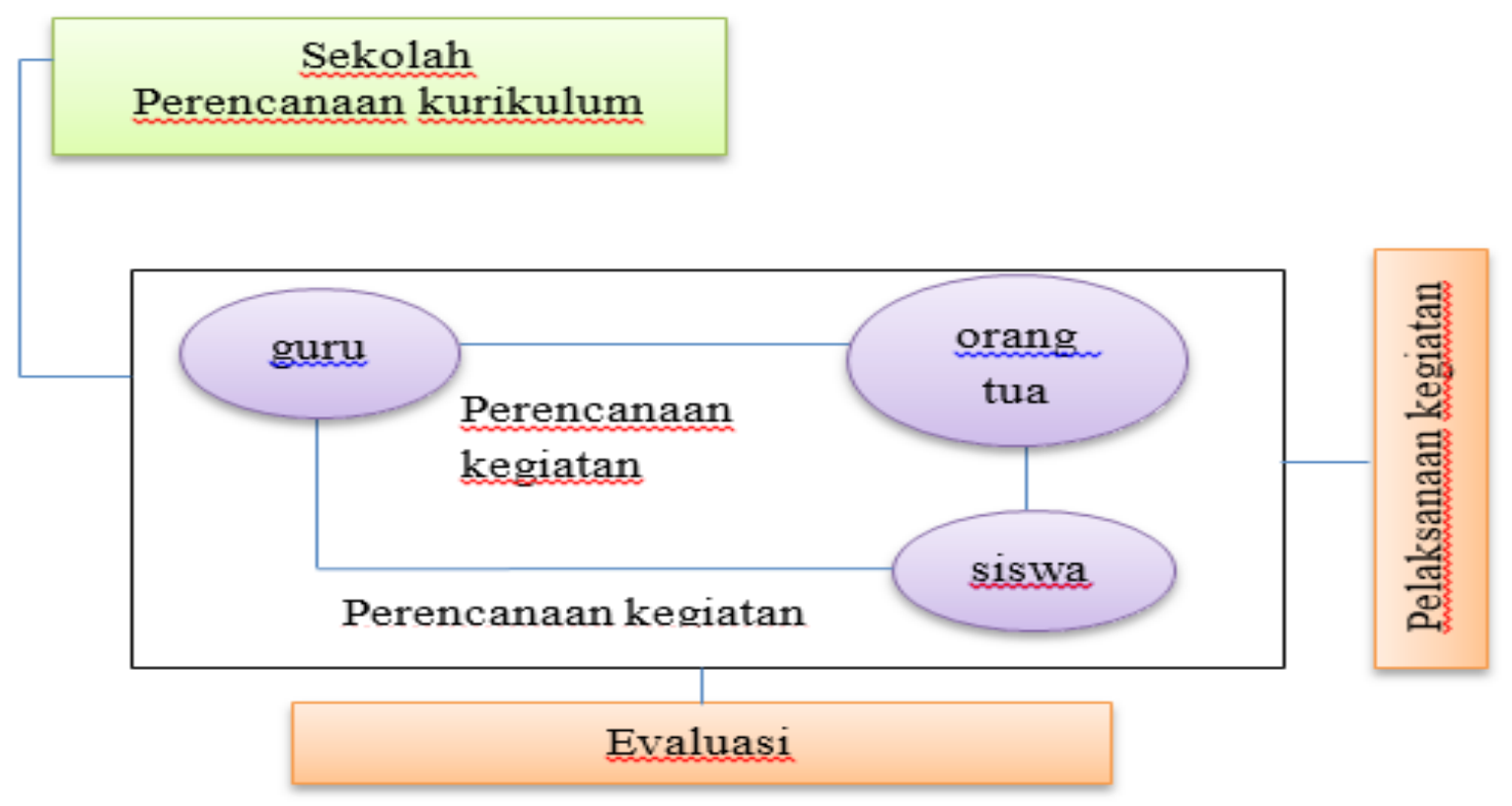

Sumber: Hasil Penelitian, 2019

\section{Gambar 4 Pola Komunikasi Guru terhadap orang tua dalam kegiatan Pembelajaran di Sekolah}

mendengarkan dan akan menguji anak-anak dengan memberikan pertanyaan-pertanyaan yang sesuai dengan tema. Jadi peran orang tua cukup dominan. Hal ini menjadi cara-cara menarik yang dapat membangun keterlibatan orang tua dalam kegiatan-kegiatan sekolah.

Dengan komunikasi, sekolah memberikan informasi terus menerus tentang kegiatan anak. Sekolah memiliki WWL (What We Will Learn) jadi setiap minggu itu orang tua mengetahui kegiatan anak yang diinformasikan melalui guru. Cara membangun komunikasi pada orang tua adalah meminta komitmen sejak awal memasukkan anaknya di sekolah. Orang tua juga dilibatkan dalam kegiatan lokakarya di sekolah. Pada kegiatan lokakarya disampaikan program sekolah selama satu semester ke depan. Pada setiap program besar, komunikasi akan dibangun kembali.

Melalui guru, buku penghubung terus diaktifkan karena baik untuk anak melatih menulis dan juga mengungkapkan perasaan dan juga bisa memantau kegiatan sekolah. Untuk komunikasi yang lebih detail digunakan Whatsapp Group dari orang tua dan guru.

Bentuk komunikasi lainnya adalah sekolah selalu memberikan video yang berisi kegiatan apa saja yang sudah dilakukan sehingga orang tua memiliki gambaran.

Guru memiliki berbagai cara agar komunikasi orang tua di sekolah terus terjalin. Diantaranya melalui kegiatan My Conference yang proyeknya $20 \%$ dikerjakan di rumah, sehingga orang tua mengetahui prosesnya. Proyek yang belum selesai sebesar 20\% penulisan akan melibatkan peran orang tua. Jadi orang tua akan sangat memahami proses ini, anak akan menjadi semangat bercerita. Secara otomatis orang tua akan meluangkan waktu untuk melibatkan diri. Keterlibatan orang tua cukup tinggi bila dilihat dari kehadiran pada My Conference. Jadwal cukup fleksibel dengan tujuan utama adalah kehadiran orang tua.

Guru terus berlatih membangun komunikasi dengan orang tua. Kegiatan-kegiatan untuk guru seperti training berkelanjutan, dilakukan setiap minggu pertemuan. Guru terus diingatkan dan dilatih keterampilan berkomunikasi, keterampilan cara menulis buku penghubung, keterampilan cara menggunakan emoticon di handphone. Kalau ada yang memerlukan perhatian khusus, perlu adanya diskusi terlebih dahulu dengan manajemen.

Komunikasi yang dibangun guru juga mengutamakan kenyamanan. Daya tarik, kesediaan dalam berkomunikasi diantaranya 
adalah dengan menciptakan suasana yang nyaman. Dan penting juga membangun komunikasi yang membuat orang tua merasa senang dan nyaman.

Konflik dengan orang tua cukup jarang terjadi. Ketidaksepahaman yang muncul akan segera diatasi walaupun jarang terjadi dan masih bisa diselesaikan dengan baik. Akan dipertemukan antara orang tua dengan guru atau pihak manajemen.

Memelihara relasi antara orang tua dengan guru sangat tidak mudah. Komunikasi yang berkelanjutan selalu dijaga, respon dari orang tua siswa selalu ditanggapi, ide-ide yang disampaikan diakomodir dengan baik, memiliki program khusus untuk mengatasi berbagai permasalahan yang dirasakan orang tua siswa. Komunikasi dengan orang tua siswa melalui berbagai dialog ternyata bisa mengatasi berbagai kendala yang muncul sehingga tercipta kenyamanan ke dua belah pihak karena berbagai permasalahan bisa diatasi dengan baik. Berbagai keluhan orang tua yang hanya disampaikan oleh pihak-pihak tertentu saja tetap direspons, dapat dilihat pada gambar 4 .

\section{SIMPULAN}

Pelaku-pelaku yang terlibat dalam pendidikan di sekolah yaitu guru, anak dan orang tua siswa menjadi bagian yang penting dalam membangun komunikasi yang efektif di sekolah. Orang tua siswa terlibat dari awal penyusunan kurikulum, bersama guru menyusun berbagai rencana pembelajaran, terlibat dalam berbagai program belajar, bahkan ikut andil dalam melakukan evaluasi belajar untuk kegiatan belajar tertentu.

Kesediaan orang tua untuk terlibat langsung dalam berbagai program belajar di sekolah karena strategi komunikasi yang diterapkan oleh Guru. Komunikasi yang dilakukan guru adalah atas dasar pemaknaan terhadap perilaku anak dalam belajar. Atas dasar pemaknaan tersebut guru menyadari pentingnya keterlibatan orang tua dalam proses belajar anak. Guru dan orang tua bekerja sama membangun dan merancang kegiatan pembelajaran yang menarik di sekolah. Kemudian melalui suatu proses penafsiran (interpretative process), anak menerima komunikasi yang dilakukan oleh guru dengan keterlibatan orang tua di dalamnya. Untuk kemudian terbentuklah pemahaman pada anak terhadap pelajaran yang diajarkan.

Guru berusaha membangun persepsi yang positif pada orang tua. Terus membangun kredibilitas termasuk menjadi pendengar yang baik ketika orang tua akan menyampaikan keluhannya. Suasana dalam berkomunikasi juga dibuat senyaman mungkin. Guru juga membangun kepercayaan pada orang tua siswa termasuk menjaga kerahasiaan apabila orang tua bercerita tentang permasalahan anaknya.

Ketertarikan orang tua siswa untuk mau terlibat di sekolah karena strategi komunikasi guru melalui perancangan berbagai program belajar yang menarik yang langsung mensyaratkan keterlibatan orang tua siswa. Selain itu untuk membangun daya tarik, guru bersama-sama dengan pihak sekolah menyelenggarakan berbagai program kegiatan dalam belajar. Dengan mendesain waktu yang tepat maka orang tua akan terlibat dalam kegiatan belajar anaknya di sekolah dalam rentang waktu yang cukup untuk memantau kegiatan belajar anak.

Namun tidak semudah itu membangun keterlibatan orang tua. Berbagai program yang menarik tetap harus dikomunikasikan secara terus menerus kepada orang tua. Menjaga komunikasi yang berkesinambungan sangat penting untuk membangun relasi yang kuat dengan orang tua siswa agar keterlibatan makin tinggi.

Komunikasi yang dibangun selalu dua arah. Kepentingan dan keinginan orang tua untuk kepentingan pendidikan anak diakomodir oleh guru sehingga masing-masing pihak merasakan manfaat yang besar untuk selalu menjalin komunikasi. Ide-ide cemerlang orang tua juga akan dapat mendorong programprogram di sekolah. Hal ini yang mendorong selalu terjadi komunikasi antara orang tua dan guru dalam kegiatan belajar anak di sekolah. Masing-masing merasakan manfaatnya dan dalam kondisi yang nyaman.

Strategi komunikasi guru dalam melibatkan orang tua pada kegiatan pendidikan anak karena kemampuan membangun komunikasi. Membangun komitmen orang tua sejak awal adalah kuncinya. Ketika orang tua akan menyekolahkan anaknya di sekolah maka Komunikasi harus dibangun sejak awal. Membangun komitmen orang tua, menyadarkan mereka bahwa aktor dalam kegiatan pendidikan 
di sekolah tidak hanya guru dan anak tetapi juga peran orang tua sangat penting.

Selain itu komunikasi harus terus dibangun secara berkesinambungan melalui berbagai program pembelajaran yang melibatkan orang tua. Membangun komitmen orang tua dengan mengkomunikasikan apa saja yang akan dilakukan orang tua dan anak ketika bersekolah di sekolah ini. Kemampuan menciptakan berbagai program yang mensyaratkan keterlibatan orang tua dalam berbagai kegiatan anak di sekolah menjadi wadah komunikasi yang menarik. Keterlibatan ini dibangun oleh guru sehingga bersama-sama dengan orang tua mengikuti perkembangan anak belajar di sekolah.

Pola komunikasi guru dalam membangun keterlibatan orang tua pada pembelajaran di sekolah terbentuk karena ketertarikan orang tua kepada berbagai program belajar di sekolah. Orang tua siswa hadir di sekolah dengan daya tarik program belajar untuk kepentingan pendidikan anak. Kebutuhan orang tua siswa untuk ikut mendampingi karena komunikasi yang dilakukan oleh guru sejak awal anak masuk sekolah. Kemampuan komunikasi guru cukup baik dan dilakukan berkelanjutan karena guru selalu meningkatkan kredibilitasnya dalam berkomunikasi melalui berbagai pelatihan yang diselenggarakan oleh sekolah dan adanya saling kontrol dengan pihak manajemen di sekolah sehingga meminimalkan munculnya konflik dan membuat orang tua merasa nyaman.

Pola komunikasi yang terbangun diawali dengan strategi komunikasi yang dilakukan oleh guru kepada orang tua siswa. Sejak awal tahun pelajaran guru sudah mulai menjalin komunikasi dengan orang tua siswa. Komunikasi yang dibangun adalah menekankan komitmen, membangun kebutuhan orang tua untuk mendampingi anak di sekolah, berkomunikasi dalam membangun keterlibatan orang tua siswa dalam mengembangkan kurikulum serta berkomunikasi untuk melakukan evaluasi bersama dalam berbagai program pembelajaran siswa.

Guru juga membangun komunikasi dengan orang tua untuk pengembangan pembelajaran di sekolah. Kebutuhan orang tua untuk mengkomunikasikan masalah atau prestasi anaknya juga diakomodir dengan baik oleh guru. Orang tua merasa nyaman, tertarik dan juga merasa butuh terlibat dalam berbagai kegiatan belajar disekolah melalui strategi komunikasi yang dilakukan oleh guru.

Sebagai saran praktis, berbagai program pembelajaran di mana ada keterlibatan orang tua siswa cukup menarik dan sukses diterapkan disekolah. Guru bisa membangun komunikasi untuk memotivasi orang tua mendorong munculnya inovasi-inovasi yang dapat menjadi kolaborasi siswa, guru dan orang tua siswa.

Sebagai saran ilmiah, pengembangan strategi komunikasi bisa diarahkan untuk mengembangkan metode pembelajaran yang dikaitkan dengan perkembangan zaman baik bidang sains dan teknologi maupun di bidang sosial humaniora.

\section{DAFTAR PUSTAKA}

Astiti, P., Suminar, J. R., \& Rahmat, A. (2018). Konstruksi identitas guru bimbingan konseling sebagai komunikator pendidikan. Jurnal Kajian Komunikasi, 6(1), 1-0. https://doi.org/https://doi.org/10.24198/ jkk.v6il

Axelsson, K., Hägglund, S., \& Sandberg, A. (2015). Entrepreneurial learning in education preschool as a take-off for the entrepreneurial self. Journal of Education and Training, 2(2), 40-58. https://doi. org/10.5296/jet.v2i2.7350

Chandran, R., \&Ariffin, M.Y.M.(2015). Beyond arbitrary labels: understanding ethnic identity development among chindians. SEARCH: The Journal of the South East Asia Research Centre for Communications and Humanities, 7(2), 1-17.

Christianti, M., Cholimah, N., \& Suprayitno, B. (2015). Development of entrepreneurship learning model for early childhood. Asia Pacific Journal of Multidisciplinary Research, 3(3), 65-70.

DeVito, J. A. (2012). The interpersonal communication book (13th ed.). New York: Pearson.

Fuglsang, L. (Ed.). (2008). Innovation and the creative process: towards innovation with care. Cheltenham: Edward Elgar Publishing Limited.

Nauta, F., Jong, J. de, \& Cels, S. (2012). Agents of change: strategy and tactics for social innovation. Virginia: Brookings Institution Press.

Putri, N. E., Hakim, N., \& Yamin, M. (2016). 
Ecologicall footprint and biocapacity analysis for flooding prevention in South Sumatera. Jurnal Mimbar, 32(1), 58-64.

Rini, Y. S. (2014). Komunikasi orang tua-anak dalam pengambilan keputusan pendidikan. Jurnal Interaksi, 3(2), 112-122.

Triwardhani, I. J. (2011). Komunikasi anak di sekolah inklusif: sebuah telaah etnografi komunikasi. Bandung: Unpad Press.

Triwardhani, I. J., \& Chaerowati, D. L. (2019). Interpersonal communication among parents and children in fishermen village in Cirebon Indonesia. Malaysian Journal of Communication, 35(2).

Wisman, Y. (2017). Komunikasi efektif dalam dunia pendidikan. Jurnal Nomosleca, 3(2). Yin, R. K. (2009). Studi kasus: desain dan metode. Jakarta: Rajagrafindo Persada.

Yu, F.-L. T. (2009). A dynamic model of the entrepreneurial process: a human agency perspective. International Journal of Innovation and Learning, 6(3). 